\title{
The effect of cycle stage and plasma progesterone level on the induction of multiple ovulations in heifers
}

\author{
J. M. Sreenan and J. P. Gosling* \\ The Agricultural Institute, Belclare, Tuam, Galway, and \\ *Biochemistry Department, University College, Galway, Ireland
}

The application of egg transfer techniques in cattle depends on a consistent supply of fertilized eggs being available, and the induction of superovulation is the main method of egg supply. Administration of follicle-stimulating compounds (mainly PMSG) during the follicular phase (Days 15 to 17) of the oestrous cycle has been the usual method used to induce multiple ovulations (see for example, Avery, Fahning \& Graham, 1962; Gordon, Williams \& Edwards, 1962; Scanlon, Sreenan \& Gordon, 1968). Because of the variability in oestrous cycle length in the cow, however, treatment of this type causes a variable onset of oestrus and ovarian response (Scanlon et al., 1968). The administration of PMSG during the luteal phase, followed by prostaglandin treatment to induce rapid luteolysis gives a consistent oestrous onset and a high ovulatory response (Elsden, Lewis, Cumming \& Lawson, 1974), the latter being higher when PMSG is given between Days 8 and 14 of the cycle (Phillipo \& Rowson, 1975).

The aim of the present studies was to examine the relationship between the endogenous progesterone level and ovulation rate in PMSG treated cows and to determine the effect of increasing the endogenous progesterone level during the early and mid-luteal phases of the oestrous cycle on the ovarian response to PMSG.

\section{Methods}

The animals were maiden heifers (Hereford $\times$ Aberdeen Angus) weighing 272-318 kg. Standing oestrus was detected with vasectomized bulls for each animal before treatment. The day of oestrus was designated as Day 0. Each heifer received an i.m. injection of 2000 i.u. PMSG (Folligon, Batch No. 2334: Intervet) on Day 3 (Group I) or Day 10 (Group II) of the oestrous cycle. Half of the heifers in each group received exogenous progesterone which was administered by an intravaginal sponge pessary inserted on Days 2 (Group I) or 9 (Group II) and removed $48 \mathrm{~h}$ after PMSG administration. All animals received $500 \mu \mathrm{g}$ cloprostenol (ICI 80,996), a prostaglandin analogue, at 48 and $72 \mathrm{~h}$ after the PMSG injection.

Oestrus and ovulation rate. After treatment, heifers were checked three times daily for the occurrence of oestrus with the aid of vasectomized bulls and were inseminated with frozen-thawed semen during standing oestrus or at $72 \mathrm{~h}$ after the first prostaglandin injection if oestrus had not been previously detected. Between Days 3 and 6 after the onset or expected onset of the induced oestrus a laparotomy was performed and the number of follicles $\geqslant 10 \mathrm{~mm}$ in diameter was counted. The ovulation rate was determined from $\mathrm{CL}$ counts and ova were recovered as previously described (Sreenan, Beehan \& Mulvehill, 1975).

Determination of plasma progesterone. Blood samples were taken by jugular venepuncture at 24-h intervals from all the animals; sampling was started on the day before progesterone pessary insertion and continued for 3 days after PMSG administration. The blood was collected in evacuated $10-\mathrm{ml}$ glass tubes containing $0 \cdot 1 \mathrm{ml}$ EDTA, cooled in an ice bath and centrifuged at $1500 \mathrm{~g}(20 \mathrm{~min}$, $5^{\circ} \mathrm{C}$ ) within $30 \mathrm{~min}$ of collection. Plasma samples were stored at $-20^{\circ} \mathrm{C}$ until assay for progesterone by the radioimmunoassay method described by Gosling, Parker \& Fottrell (1975). Duplicate $0.2 \mathrm{ml}$ aliquots of all samples were extracted with $0.5 \mathrm{ml}$ petroleum ether. For each assay run, low level plasma samples with 250 or $1000 \mathrm{pg}$ added progesterone standard were included. These gave mean recovery values of 284 and $1000 \mathrm{pg}$, respectively. The extraction efficiency was $90 \cdot 0 \pm 4 \cdot 8$ (S.D.) \% and the results were corrected for such losses. Each assay run included samples from all animals. Interassay variation for control samples containing $5 \mathrm{ng}$ progesterone $/ \mathrm{ml}$ was $9 \cdot 2 \%$. 
Statistical analysis. Ovarian response and plasma progesterone levels were analysed by least squares analysis (Harvey, 1960), with logarithmic transformation of the progesterone determinations.

\section{Results and discussion}

Exogenous progesterone resulted in increased plasma levels at the time of PMSG administration for animals in Group I $(3.3 \pm 0.5$ versus $0.3 \pm 0.5 \mathrm{ng} / \mathrm{ml}, P<0.01)$ and while animals treated with progesterone at Day 10 (Group II) had a higher mean value, the difference was not significant $(8 \cdot 0 \pm 0.7$ and $6.6 \pm 1 \cdot 0 \mathrm{ng} / \mathrm{ml})$.

As shown in Table 1, ovulation rate was significantly higher $(P<0.01)$ in Group II than in Group I animals but exogenous progesterone did not affect the ovulation rate in either group. The higher numbers of recovered and fertilized ova in Group II $+\mathbf{P}$ are a reflection of the higher ovulation rate in these animals. The rates of ovum recovery are consistent with those obtained by other workers (see Foote \& Onuma, 1970).

Table 1. Effect of day of cycle and time of treatment with exogenous progesterone $(P)$ on ovarian response to PMSG in heifers

\begin{tabular}{lccccc}
\hline & \multicolumn{2}{c}{ Group I } & & \multicolumn{2}{c}{ Group II } \\
\cline { 2 - 3 } \cline { 5 - 6 } & $-\mathrm{P}$ & $+\mathrm{P}$ & & $-\mathrm{P}$ & $+\mathrm{P}$ \\
\hline No. of heifers & 10 & 10 & & 16 & 17 \\
No. of CL* & $6.9 \pm 2 \cdot 8^{\mathrm{a}}$ & $6 \cdot 8 \pm 2 \cdot 8^{\mathrm{a}}$ & & $11 \cdot 5 \pm 2 \cdot 1^{\mathrm{b}}$ & $15 \cdot 2 \pm 2 \cdot 1^{\mathrm{b}}$ \\
No. of follicles $(\geqslant 10 \mathrm{~mm}$ diam.)* & $6 \cdot 6 \pm 1 \cdot 7$ & $5 \cdot 4 \pm 1 \cdot 6$ & & $4 \cdot 3 \pm 1 \cdot 3$ & $3 \cdot 2 \pm 1 \cdot 3$ \\
No. of ova recovered* & $5 \cdot 1 \pm 1 \cdot 3$ & $4 \cdot 8 \pm 1 \cdot 8$ & & $6 \cdot 5 \pm 1 \cdot 8$ & $9 \cdot 3 \pm 2 \cdot 3$ \\
No. of fertilized ova & $3 \cdot 6 \pm 1 \cdot 2$ & $2 \cdot 9 \pm 1 \cdot 3$ & & $4 \cdot 7 \pm 1 \cdot 3$ & $6.9 \pm 0.9$ \\
\hline
\end{tabular}

Values $( \pm$ S.E.M. $)$ with different superscripts are significantly different $(P<0.01)$.

* At laparotomy on Days 3-6 of the induced oestrus.

Table 2. Correlation coefficients between plasma progesterone level and ovulation rate in heifers on different days following treatment with PMSG (Day 3 or 10)

\begin{tabular}{lc}
\hline & $\begin{array}{c}\text { Correlation coefficient } \\
(r)\end{array}$ \\
\hline Day of PMSG administration & -0.0132 \\
+1 day & $0 \cdot 1651$ \\
+2 days & $0 \cdot 1324$ \\
+3 days & $0 \cdot 0810$ \\
All 4 days & $0 \cdot 1123$ \\
\hline
\end{tabular}

There was no evidence for a significant correlation between plasma progesterone level and ovulation rate at any of the days examined (Table 2). These results are in agreement with those of Nancarrow \& Miller (1975) who also found a low correlation coefficient $(r=-0 \cdot 055)$.

Little information is available on the factors affecting follicular growth and ovulation in response to gonadotrophic stimulation in the cow. Henricks, Hill, Dickey \& Lamond (1973) infer from their studies that the critical factor controlling ovulation rate in superovulating cows may be the number of follicles induced to grow and secrete oestrogen while the $C L$ is still actively producing progesterone. We found that increasing the endogenous progesterone level early (Day 3 ) or in the middle (Day 10) of the cycle did not affect the ovulation rate (Table 1) but that the day of the cycle on which PMSG was administered was important, confirming the reports of Phillipo \& Rowson (1975) and Newcomb \& Rowson (1976).

In the present study the follicular response (no. of follicles $\geqslant 10 \mathrm{~mm}$ in diam.) and the total ovarian response (follicles $\geqslant 10 \mathrm{~mm}+\mathrm{CL}$ ) were not affected by the day of the cycle on which PMSG was 
administered. It is probable therefore that it is the type of follicle population in the ovary at any particular time rather than the number that affects the ovulation response to gonadotrophin.

Further studies are required to determine whether the interaction between progesterone and other hormones may in fact affect the response to PMSG stimulation.

We thank Mr M. J. Cooper, ICI Ltd, for the ICI 80,996; Mrs A. Glynn and Mr A. McDonagh for excellent technical assistance; and Mr G. Morris, Mr D. Morris and Mr P. Creaven for help at all stages of this work, which was supported by the Commission of the European Communities.

\section{References}

Avery, T.L., Fahning, M.L. \& Graham, E.F. (1962) Investigations associated with the transplantation of bovine ova. II. Superovulation. J. Reprod. Fert. 3, 212-217.

Elsden, R.P., Lewis, S., Cumming, I.A. \& Lawson, R.A.S. (1974) Superovulation in the cow following treatment with PMSG and prostaglandin $\mathbf{F}_{2 x} . J$. Reprod. Fert. 36, 455-456.

Foote, R.H. \& ONUMA, H. (1970) Superovulation, ovum collection, culture and transfer. A review. $J$. Dairy Sci. 53, 1681-1692.

Gordon, I., Williams, G.L. \& Edwards, J. (1962) The use of PMS (serum gonadotrophin) in the induction of twin pregnancy in the cow. J. agric. Sci., Camb. 59, 143-198.

Gosling, J.P., Parker, W. \& Fottrell, P.F. (1975) The routine operation of a radioimmunoassay for progesterone in bovine and ovine plasma. In Radioimmunoassay in Clinical Biochemistry. Ed. C.A. Pasternak. Hayden, London., pp. 177183.

HARVEY, W.R. (1960) Least Squares Analysis of Data. U.S.D.A. Published No. ARS 20-8.
HeNRICKs, D.M., HILl, J.R., DiCKey J.F. \& LAMOND, D.R. (1973) Plasma hormone levels in beef cows with induced multiple ovulation. $J$. Reprod. Fert. 35, 225-233.

NanCarrow, C.D. \& Miller, W.J.B. (1975) Factors influencing oestrus synchronization relative to superovulation and egg transfer. Proc. E.E.C. Seminar, Egg Transfer in Cattle, Cambridge pp. 291-300.

Newcomв, R. \& Rowson, L.E.A. (1976) Multiple ovulation, egg transplantation towards twinning. In Principles of Cattle Production, pp. 59-83. Eds $\mathrm{H}$. Swan \& W.H. Broster. Butterworths, London.

Phill.IPo, M. \& Rowson, L.E.A. (1975) Prostaglandins and superovulation in the bovine. Annls Biol. anim. Biochim. Biophys. 15, 233-240.

Scanlon, P., Sreenan, J. \& Gordon, I. (1968) Hormonal induction of superovulation in cattle. $J$. agric. Sci., Camb. 70, 179-182.

Sreenan, J.M., Beehan, D. \& Mulvehill, P. (1975) Egg transfer in the cow: factors affecting pregnancy and twinning rates following bilateral transfers. $J$. Reprod. Fert. 44, 77-85. 